\title{
Potential Candidate Genes for Improving Rice Disease Resistance
}

\author{
Amandine Delteil • Jie Zhang • Philippe Lessard • \\ Jean-Benoit Morel
}

Received: 8 September 2009 /Accepted: 20 December 2009/Published online: 16 January 2010

(C) The Author(s) 2010. This article is published with open access at Springerlink.com

\begin{abstract}
Diseases caused by fungal and bacterial pathogens like Magnaporthe oryzae and Xanthomonas oryzae pv. oryzae are responsible for considerable yield loss. Up to now, in rice, the modification of the expression of more than 60 genes from diverse origins has shown beneficial effects with respect to disease resistance. In this paper, we review this large set of data to identify the best genes and strategies to achieve disease resistance by transgenic approaches. Altered expression of genes involved in signal transduction and transcription may lead to many unwanted side effects, like lesion mimic phenotypes. Moreover, modification of resistance to abiotic stress has been neglected and should be carefully examined in the future. Genes like resistance genes and pathogenesis-related genes can confer broad spectrum and high levels of resistance to several pathogens. Preformed expression of defense is often observed but does not necessarily lead to detrimental effects. Although examples
\end{abstract}

Electronic supplementary material The online version of this article (doi:10.1007/s12284-009-9035-x) contains supplementary material, which is available to authorized users.

A. Delteil · J.-B. Morel $(\triangle)$

UMR BGPI INRA/CIRAD/SupAgro,

Campus International de Baillarguet,

TA A $54 / \mathrm{K}$,

34398 Montpellier, France

e-mail: jbmorel@cirad.fr

\section{J. Zhang}

Shanghai LongPing Agricultural Biotechnology Co. Ltd,

300 Fenglin Road,

200032 Shanghai, People's Republic of China

\section{P. Lessard}

Limagrain China,

1-2501, Beifangmingzhu Building, No. 1 Zhongtancun,

Dongxiakouzhen, Changping District,

102218 Beijing, People's Republic of China of gene pyramiding are scarce, they suggest that this is a very promising strategy. More field evaluation of the transgenic plants is required to draw final conclusions on the usefulness of these genes for improving disease resistance.

Keywords Rice $\cdot$ Transgenic plant $\cdot$ Disease resistance

\section{Introduction}

To meet the increasing demand on the world food supply, we will have to produce up to $40 \%$ more rice by 2030 (Khush 2005). This will have to be on a reduced sowing area due to urbanization and increasing environmental pollution. For example, the sowing area in China decreased by eight million hectares between 1996 and 2007 (China Statistical Bureau; http://www.stats.gov.cn/english/statisticaldata/yearlydata/). Improvement of yield per plant is not the only way to achieve this goal; reduction of losses by biotic and abiotic stress is also a solution. According to FAO estimates, diseases, insects, and weeds cause as much as $25 \%$ yield losses annually in cereal crops (Khush 2005). In particular, fungal diseases can cause important losses (between $1 \%$ and $10 \%$ ) regionally (Savary et al. 2000). In China alone, it is estimated that one million hectares are lost annually because of blast disease (Khush et al. 2009).

Fungal and bacterial pathogens represent a permanent threat on rice cultivation. Between 1987 and 1996, fungicides represented up to $20 \%$ and $30 \%$ of the culture costs in China (\$46 million) and Japan (\$461 million) respectively, whereas they represent approximately $10 \%$ of the costs in Europe and the USA (http://beta.irri.org/solutions/). Thus, a strong effort has been invested in improving disease resistance. These efforts could now benefit from the 
knowledge gained on mechanisms underlying disease resistance.

Since the initial definition of the plant resistance $(R)$ genes by Flor (1942), many $R$ genes have been identified. The vast majority of the known $R$ genes is composed of proteins carrying nucleotide-binding sites and leucine-rich repeat motifs (NBS-LRR; Jones and Dangl 2006). Most $R$ genes recognize pathogen effectors developed by pathogens to inhibit defense, although there are a few exceptions (e.g., Lee et al. 2009). Some of these effectors thus correspond to the initial definition by Flor of the avirulence gene. Depending on the presence/absence of these $R$ genes and of the matching avirulence product, the interaction will be incompatible (plant is resistant) or compatible (plant is susceptible).

Many $R$ genes have been identified in rice and most code for NBS-LRR genes (Ballini et al. 2008; White and Yang 2009). After recognition mediated by the $R$ gene, signal transduction occurs and requires regulators such as MAP kinases (Mishra et al. 2006). Finally, transcription factors like WKRYs activate a deep transcriptional reprogramming of the cell (Eulgem 2005), leading to the activation of defense responses per se. These include production of antimicrobial secondary metabolites (phytoalexins like momilactones in rice; Peters 2006), pathogenesis-related (PR) proteins (e.g., chitinases, glucanases, PBZ1 in rice; Jwa et al. 2006; van Loon et al. 2006), cell wall strengthening (Hückelhoven 2007), and programmed cell death, leading to hypersensitive response (HR; Greenberg and Yao 2004). The genes that act downstream of the disease resistance pathway are collectively called defense genes.

Most of the elements involved (receptors, regulators, transcription factors, and defense genes) are well conserved across species. For example, the NPR1 gene is a central regulator in both monocots and dicots. The NPR1 gene was successfully used in several plant species like Arabidopsis (Cao et al. 1998), rice (Chern et al. 2001), tomato (Ekengren et al. 2003), and wheat (Makandar et al. 2006). Similarly, the mlo gene functions in barley (Peterhänsel and Lahaye 2005), tomato (Bai et al. 2008), and Arabidopsis (Consonni et al. 2006). These observations are critical for biotechnology approaches since they suggest that one gene from one species can provide an interesting trait in another.

Preformed defense systems likely play a role in basal resistance in limiting the growth of a normally virulent pathogen. Preformed or constitutive defense systems involve cuticle (Skamnioti and Gurr 2007) and cell wall (Juge 2006) strengthening. In rice, like in other plants, silicon accumulation plays direct and indirect roles in basal resistance (Ma and Yamaji 2006). Antimicrobial molecules, called phytoanticipins, can also accumulate before infection (Morrissey and Osbourn 1999). Increasing information from Arabidopsis and other plants indicates that the overproduction of PR proteins confers resistance, that mutations in regulator genes negatively regulating disease resistance can increase defense gene expression (e.g. Noutoshi et al. 2005; Petersen et al. 2000), or that over-expression of regulator genes acting positively on disease resistance can increase defense gene expression (Hammond-Kosack and Parker 2003).

More than 60 genes have now been over-expressed or mutated in rice for fundamental or applied research. Molecular and biological studies of these transgenic plants allow a better understanding of signaling pathways, cross talks, and pathogen specificities. These experiments lead to the putative disease resistance pathway shown in Fig. 1. This figure illustrates that genes in the three major steps of the disease resistance pathway are known in rice, opening the possibility to assess the usefulness of each category of gene.

Rice stable transformation via Agrobacterium tumefaciens has become a routine technique in laboratories (Toki et al. 2006). Nowadays, even if japonica is frequently used because it is highly amenable to transformation, indica transformation efficiency has sufficiently improved to allow its use in functional validation experiments and field trials in the appropriate environments.

A tool kit for breeders for marker-assisted selection was recently described (Ballini et al. 2009). Here, we extensively review the cases of improvement of disease resistance by over-expression of transgenes. Rice blast caused by the fungus Magnaporthe oryzae and bacterial blight caused by Xanthomonas oryzae pv. oryzae are the most serious and widespread diseases in rice production. Therefore, we focused this paper on these two pathogens. We did not review the abundant literature on strategies to increase insect resistance (see for example Ye et al. 2009 and references therein). We provide guidelines for selecting transgenic strategies for fungal and bacterial disease improvement, for selecting genes, and analyzing their effects. General elements on the different possible strategies to improve disease resistance in plants were previously described (Campbell et al. 2002) and are not presented here.

\section{Rice genes improving disease resistance}

Sixty rice genes for which improvement of disease resistance was shown are presented in Tables 1, 2, 3, and 4. We selected a gene only if the corresponding paper provided data concerning in vivo resistance and some information on the spectrum of pathogens that were tested. These genes were separated into three major groups: 41 rice genes (Table 1 is a selection of 24 the most characteristic genes, the remaining genes are in Electronic supplementary materials (ESM), Supplemental Table 2), five genes from plants other than rice (Table 2), and nine genes from organisms that are not plants (Table 3). Finally, we also review five cases of gene pyramiding (Table 4). Figure 1 provides a few examples of 


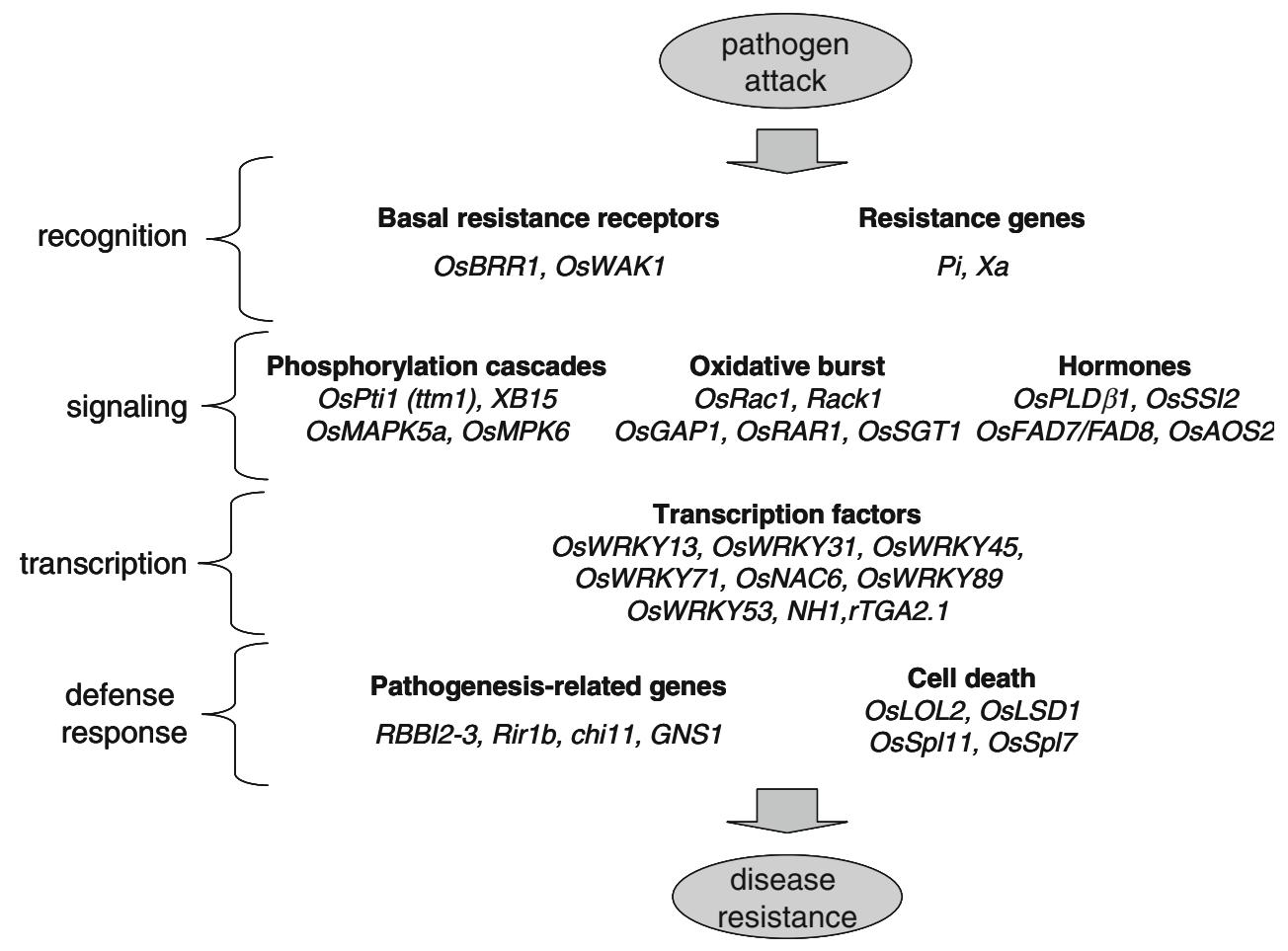

Fig. 1 Position in the putative disease resistance signaling pathway of the rice genes that were used in plants to improve disease resistance. The genes listed here are the ones for which the demonstration of usefulness was made in planta. Details on these genes are provided in Table 1.The position of the OsDR8, OsDR10, pi21, spl18, and OsSBP genes is not shown. This schematic view illustrates the three steps leading to pathogen resistance: recognition via general (e.g., OsWAK1)

where the rice genes are likely acting. Although the genes tested were not all precisely positioned on the disease resistance pathway, they can be tentatively attributed to four major steps in this pathway: recognition, signaling, transcription, and defense response.

Major resistance genes for Xanthomonas resistance ( $\mathrm{Xa}$ genes) and blast resistance ( $P i$ genes) were recently reviewed by White and Yang (2009) and Ballini et al (2008), respectively. We selected only a few examples (Pi9 and $\mathrm{Xa21}$ ) to illustrate the use of these $R$ genes in transgenics. Other genes coding for receptor-like proteins likely involved in basal resistance such as OsWAK1 and OsBRR1 were also included in our study. These two genes may have broad-spectrum effects since at least for blast disease, they were not identified as major resistance genes.

Genes with a role in signaling and transcription factors represent the majority of the cases (30 out of 41 genes) found in the literature. Although most of the transgenics built in these reports were initially obtained for fundamental research, they also provide information on their potential for protecting plants from disease. Eight of these genes (SPL11, XB15, OsPLDB1, OsRac1, SPL18, PACK1, $O s G A P 1$, and $O s D R 8)$ were originally found in rice, and specific receptors ( $P i$ and $X a$ genes), signal transduction, transcription, and defense response, involving pathogenesis-related genes and cell death. The OsPLD $\beta, O s F A D 7 / F A D 8$, and OsAOS 2 genes are involved in the jasmonic acid pathway and OSSSI2 in the salicylic acid pathway. The OsLOL2, OsLSD1, OsSpl11, and OsSpl7genes are negative regulators of cell death, and mutants for these genes display spontaneous lesions resembling disease.

whereas the other genes were found by homology to genes in other models (ex NH1 in Arabidopsis and OsPtil in tomato).

Out of the nine transcription factors identified in the literature, six are WRKYs. Their detailed effects on disease resistance were recently reviewed (Pandey and Somssich 2009). WRKYs are also known to be involved in abiotic stress response and development. The challenge in using $W R K Y$ genes in transgenic is to identify genes that have a positive effect on resistance and no or little detrimental effects on abiotic stress and/or development.

Although $14 P R$ protein families are known in rice (Van Loon et al. 2006), only $P R$ genes from a few families have been over-expressed.

\section{Other plant genes improving rice disease resistance}

A few genes from plants other than rice have been tested in rice (Table 2). Not surprisingly, the central regulatory gene NPR1 (Cao et al. 1998) belongs to this group of genes. Three $P R$ genes are also found, suggesting a good potential for this large category of genes. However, more than 50 


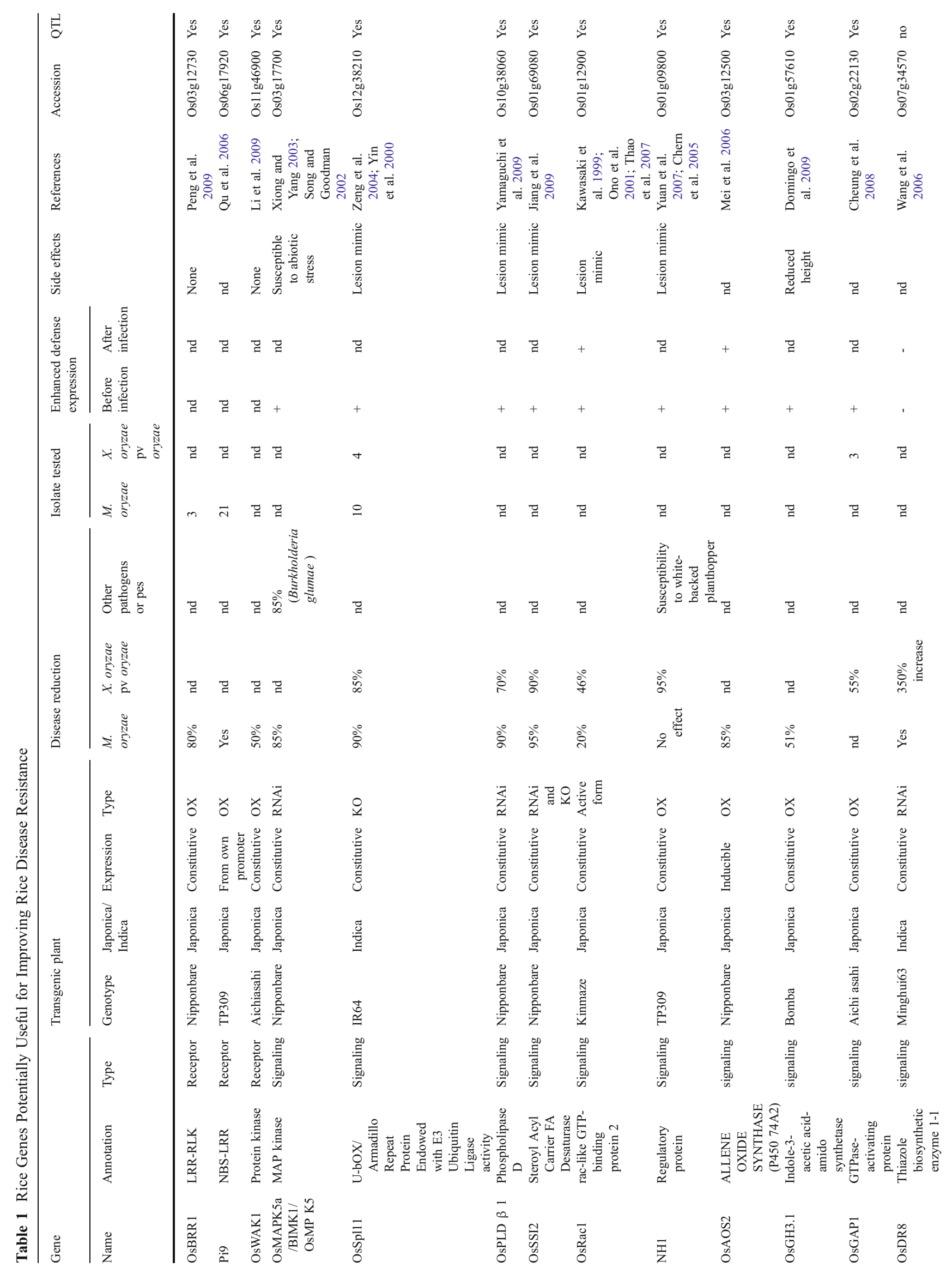




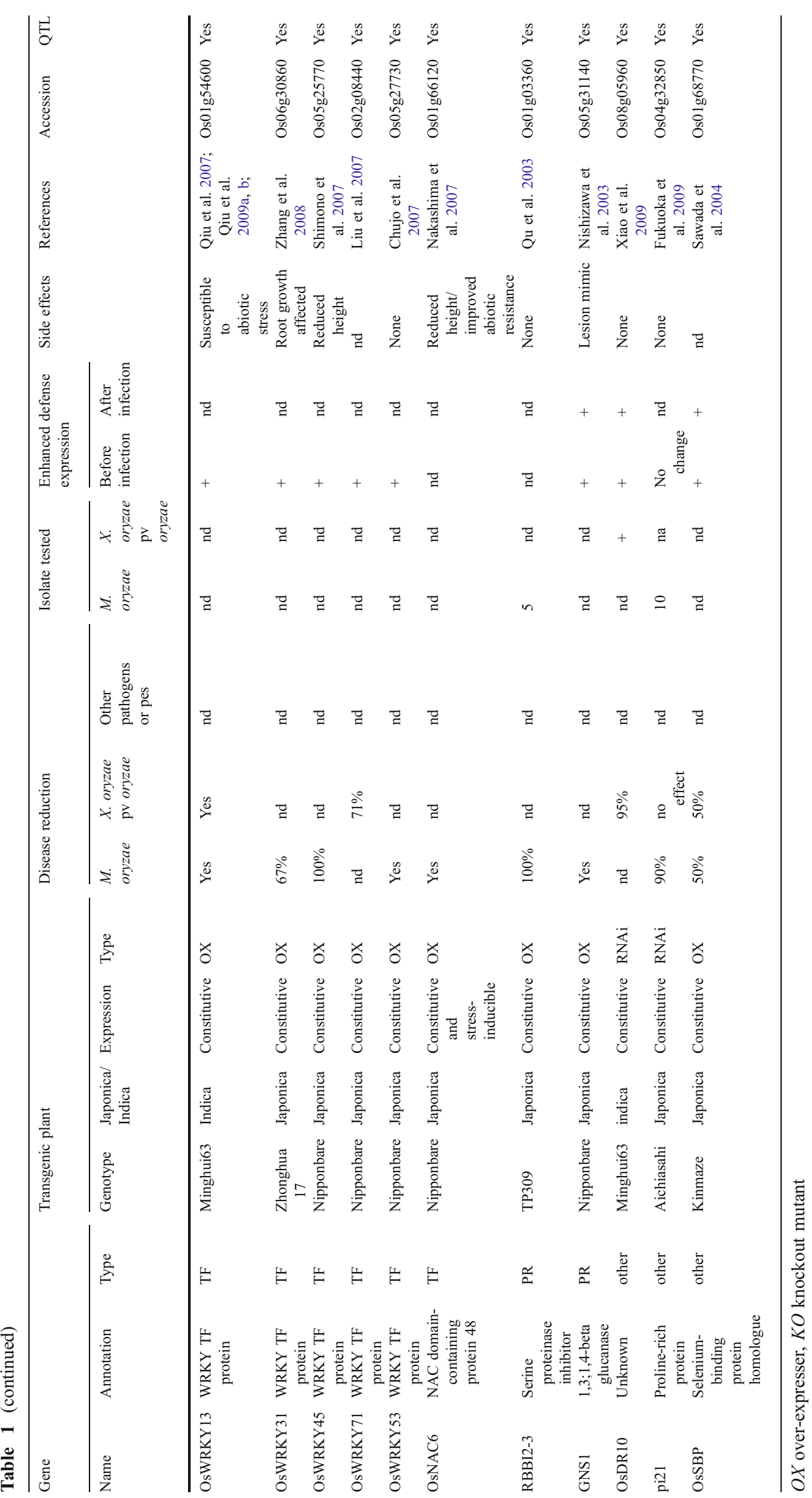




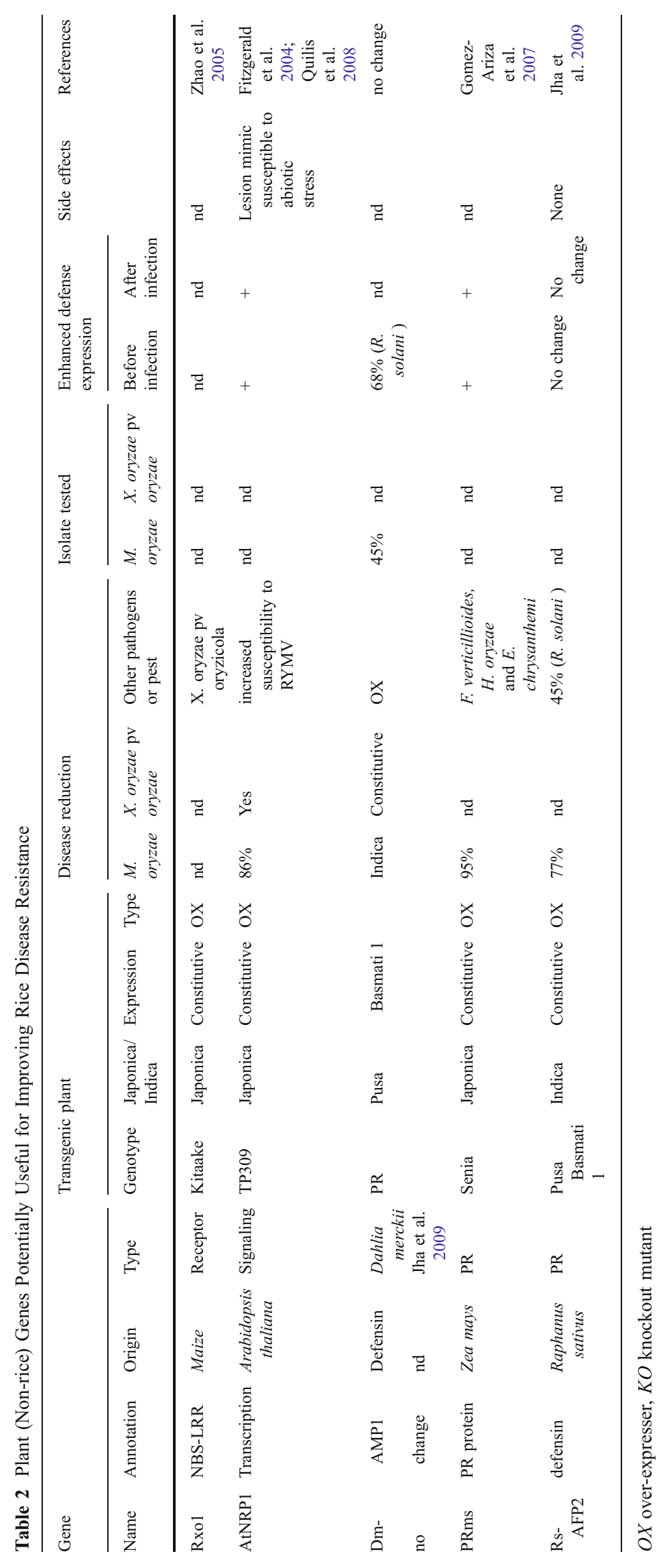




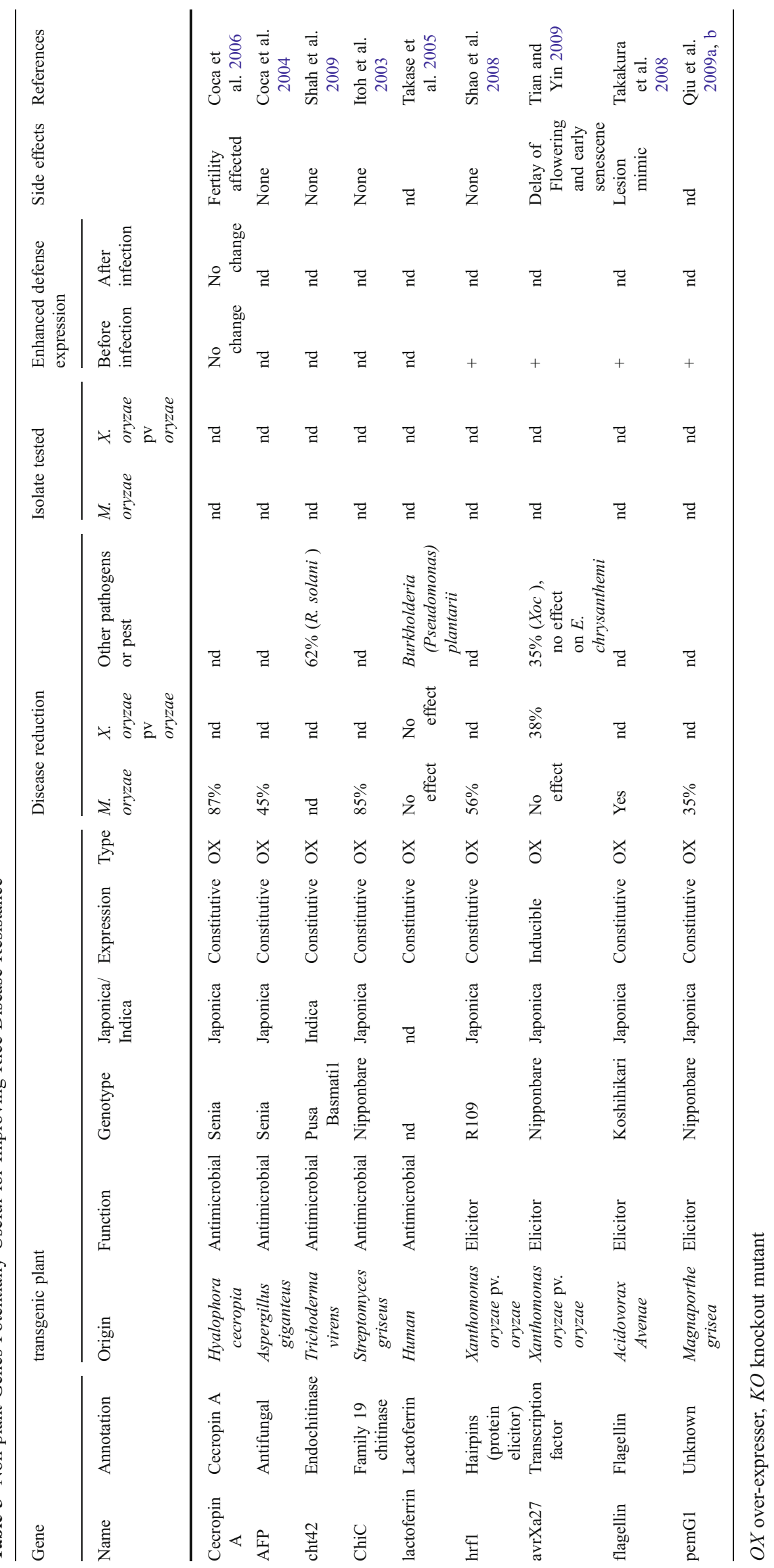




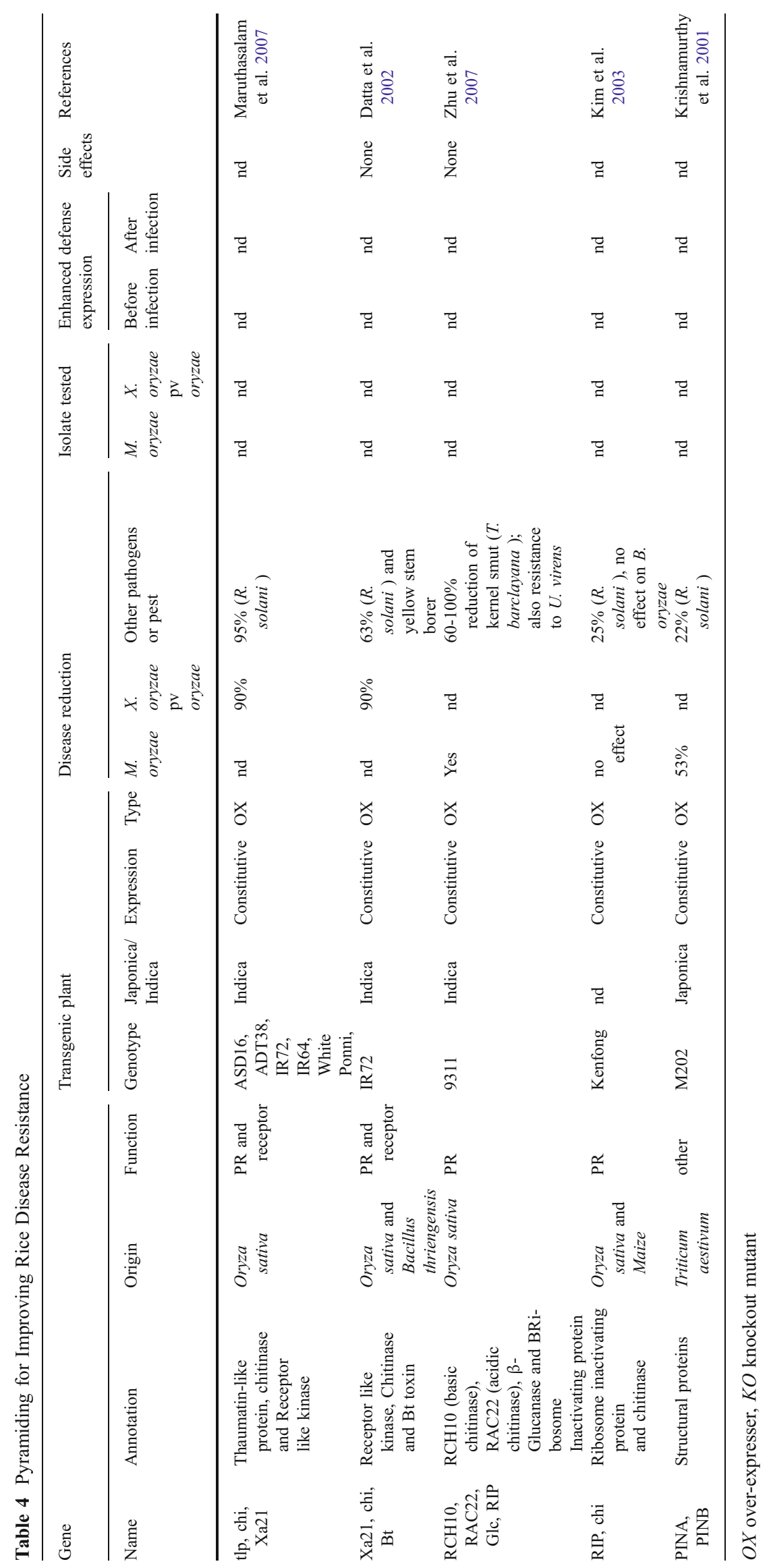


genes have now been identified in different plant species as regulating disease resistance (Hammond-Kosack and Parker 2003). Although some of these genes may not work in rice for biological reasons, the important conservation of the disease resistance pathways between plants should allow transfer from one plant to another. There is therefore a large potential in this category of genes.

Transferring one gene from one species to another may lead to unexpected effects. This was the case when the Arabidopsis NPRlgene was transferred to rice (Fitzgerald et al. 2004). The rice plants over-expressing AtNPRl also displayed an environmentally regulated and heritable lesion mimic phenotype (see below).

Moreover, a recent report on OsWRKY45 demonstrates that over-expressing (in japonica rice) a japonica allele of the gene confers increased susceptibility to bacterial blight, whereas over-expressing an indica allele of the gene confers increased resistance to bacterial blight. In contrast, both alleles conferred increased resistance to blast disease (Tao et al. 2009). This finding suggests that one should be careful when transferring one gene from one background to another, even within the Oryza sativa species.

\section{Non-plant genes improving rice disease resistance}

Table 3 summarizes available data on non-plant genes. Two types of genes were used. One group of genes is represented by proteins having known antimicrobial effects. Most of the genes reported are from fungi, one is an insect gene (Cecropin A), and one a human gene (lactoferrin). Side effects could be expected in these cases. For example, Cecropin A is a known anticancer molecule (Mader and Hoskin 2006). Moreover, the acceptance of plants for human food containing a human protein is likely to be very low.

A second group of genes like avirulence genes are known to activate plant defense responses. In this case, one expects that constitutive or inducible activation of defenses will increase disease resistance. When avirulence genes are used (e.g., avrXa27), pathogen-specific effects are expected. For this reason, most of the cases deal with avirulence genes that are broadly distributed (e.g., flagellin).

There is also a risk that such plants may show unwanted effects because such genes have a strong potential in inducing defense responses. For this reason, it is recommended to use pathogen-inducible promoters. However, such promoters are often either leaky or controlled by developmental signals (Van Loon et al. 2006). Thus, the genes that activate plant defense responses are unlikely to be a good strategy to increase disease resistance.

We excluded from this review 19 rice genes for several reasons (ESM, Supplemental Table 1). First, we excluded genes that have only been tested in heterologous systems. Second, we did not include rice genes for which only negative effects on disease resistance were reported in rice. This is for example the case of the over-expression of the $O s M T 2 b$ gene that confers enhanced susceptibility to blast (Wong et al. 2004). Finally, there were genes that had only been tested in rice cell cultures but not in entire rice plants. There is thus no in planta demonstration of the usefulness of these genes. These genes should be tested by stable transformation in rice.

\section{Disease protection quantitative effects}

Where possible, we quantitatively evaluated the level of resistance. The increase of resistance was measured as the percentage of disease reduction as compared to the presented wild-type controls. It is noteworthy that in most cases, the best control was missing. This control consists in the nullizygous plant, i.e., a non-transgenic sibling originating from a hemizygous plant. In most cases, the control shown is a transformed plant with the empty vector. Since rice transformation induces many somaclonal mutations, such a control is inappropriate. In other cases (e.g., $\mathrm{NH1}$; Chern et al. 2001), several transgenics are presented, highlighting the fact that different insertion events can show large differences. Moreover, the disease protection values were obtained from data obtained on a few plants. Only field evaluation in natural conditions could give a real idea of the effectiveness of these genes. With these caveats in mind, effects smaller than $50 \%$ should be considered as weak. For bacterial blight disease, the same criterion was always used (length of lesions), whereas for blast disease resistance, many criteria were used (lesion number, diseased area, etc.). In all cases, the value presented is the most favorable.

Independently of the pathogen, the majority of the reported cases show disease reduction higher than $50 \%$. For blast, two genes (RBBI2-3 and WRKY45; Table 1) showed the best effects with a complete absence of symptoms. Disease reduction higher than $90 \%$ was obtained with four other rice genes (Table 1) and the $P R m$ gene from maize (Table 2).

For bacterial blight, the best levels of resistance (higher than $95 \%$ reduction of disease) were achieved with two rice genes (OsDR10 and NH1; Table 1) and with two cases of pyramiding (Table 4).

For sheath blight caused by Rhizoctonia solani, the best level was achieved with pyramiding three genes (thaumatin-like protein, chitinase, and Xa21; Table 4). In this case, the data also indicate that this strong effect is only due to the combined action of the thaumatin-like and chitinase proteins, independently of the Xa21 gene (Maruthasalam et 
al. 2007). Some excellent levels of protection were also shown for kernel smut (caused by Tilletia barclayana; Zhu et al. 2007) by pyramiding (Table 4).

Pyramiding was a good strategy to increase quantitative effects of individual transgenes. For example, while the single chitinase and thaumatin-like genes each conferred about $80 \%$ increase of resistance toward sheath blight, the combination of the two genes showed a reduction of $95 \%$ of disease.

These different examples of gene pyramiding clearly demonstrate that it is a good strategy to quantitatively improve resistance. From the quantitative point of view, it is noteworthy that all categories of genes (except $R$ genes) provide, on average, the same levels of resistance.

\section{Disease protection qualitative effects}

As pathogen populations are quite complex, it is important to have an evaluation of the spectrum of action of the tested genes. Unfortunately, this information is lacking in most cases. For 27/60 genes, only one isolate of one pathogen was tested. Clear information on the spectrum of resistance was provided for only 11 genes. For blast resistance, nine genes were shown to provide resistance to more than one isolate, including $R B B I 2-3$ and Pi21 that also show elevated quantitative effects (Table 1). For blight resistance, five genes showed relatively broad-spectrum resistance, including OsDR10 plants that have high levels of resistance. The SPL11 gene was the only one for which broad-spectrum resistance was shown against both pathogens. However, these plants suffer from strong developmental side effects (see below).

There are 15 genes for which both blast and blight disease resistance have been evaluated (Tables 1, 2, and 3). All genes protecting against blast, except the pi21 gene, were shown to also confer resistance to blight. This is a very promising observation showing that the genes used for one pathogen can be used for another. It is noteworthy that the $\mathrm{NH} 1$ gene, a key disease pathway regulator, does not seem efficient against blast disease, whereas it confers good levels against blight (Chern et al. 2005; Yuan et al. 2007).

Quite surprisingly, the expression of the avrXa27 gene, in the presence of the $\mathrm{Xa27}$ gene, did not confer resistance to blast. This may be due to the lack of induction of the avrXa27 gene under the control of the inducible PRI promoter. However, the $P R 1$ gene is known to be induced by $M$. oryzae (Mitsuhara et al. 2008). Alternatively, it is likely that the events triggered by the Xa27 gene are not efficient against $M$. oryzae.

There is so far no report of simultaneous improvement of resistance against blast, blight, and sheath blight diseases.
This may be simply due to the absence of data rather than to biological reasons since there are genes conferring enhanced resistance to all combinations of two of these pathogens.

\section{Expression of defense in transgenics}

For some plant genes encoding proteins involved in disease resistance (Tables 1 and 2) and encoding avirulence products (Table 3), one can expect perturbation of the events downstream of the pathway, like $P R$ gene expression and phytoalexin production. These perturbations can occur either before and/or after infection. Defense gene expression, often using the $P R 1$ and $P B Z 1$ genes as markers, was evaluated for a large number of cases (37/55).

Elevated defense gene expression before infection was found in $80 \%$ of the cases, and these levels could be extremely high. For example, $P B Z 1$ and a peroxidase gene were found to be expressed 40 times higher in overexpressor plants as compared to wild type in the case of the WRKY53 gene (Chujo et al. 2007). Some upstream signaling events were measured in a few cases. The signaling molecule jasmonic acid was found to be less present in plants over-expressing the WRKY13 gene (Qiu et al. 2007). Similarly, reactive oxygen species were detected in several cases (e. g., OSPLD $\beta 1$, Yamaguchi et al. 2009; flagellin, Takakura et al. 2008). In one puzzling case, OsDR8, many PRs were down-regulated before (and after) infection, although the plants showed slightly enhanced resistance to blast and a strong increase of susceptibility to bacterial blight (Wang et al. 2006; Table 1). Available micro-array data on over-expressor plants further indicate that defense responses are often widely constitutively overexpressed. For example, 84 genes annotated as responsive to abiotic stress are up-regulated in plants over-expressing OsGH3.1 (Domingo et al. 2009). Similarly, more than 430 genes involved in secondary metabolite synthesis are upregulated in plants over-expressing $O s W R K Y 13$, leading to increased production of the phytoalexin momilactone (Qiu et al. 2009a, b).

An enhanced defense response after infection was observed in eight cases. This was rather expected for most of them since they encode positive regulators of defense. This was less expected for the GNS1 gene (Nishizawa et al. 2003) since this gene encodes a classical glucanase. It is possible that enhanced degradation of the cell wall of $M$. oryzae by the additional glucanase activity led to the release of molecules that in turn over-induced the defense system. No change of defense induction was observed for five genes (Cecropin A, Dm-AMP1, rTGA2.1, OsMPK6 and Rs-AFP2; Tables 1, 2, and 3) in spite of increased resistance. 


\section{Side effects}

For 19 cases, there was no specific mention of side effects. No major visible side effects were clearly found for 13 genes. It is noteworthy that for six of these 32 genes for which there are likely little or no visible side effects (OsAOS2, Rack1, OsWRKY71, OsWRKY53, OsGAP1, and OsSBP; Table 1), enhanced defense expression before infection was measured. This suggests that it is possible to increase preformed defense and disease resistance with no obvious side effect. This seems particularly clear for the plants over-expressing OsWRKY53 (Chujo et al. 2007). In this case, more than 200 genes are up-regulated as indicated by micro-array analysis, and one third of these genes, besides genes related to defense, are related to metabolism, transport, proteolysis, and signal transduction.

However, there are 28 cases for which detrimental side effects were reported. Side effects were found with all kinds of genes except receptor genes, although this may be due to an absence of data. Genes involved in signaling and transcription factors appeared to display frequent secondary effects, with $82 \%$ and $70 \%$ of the observed cases, respectively. Although the number of reported cases is scarce, avirulence genes also produced secondary effects (Table 3 ).

There were eight rice genes (OsMPK6, OsPtil, XB15, OsPLD 1 1, OsSSI2, OsRac1, NH1, and GNS1; Table 1) and one bacterial gene (flagellin; Table 3) where an unexpected lesion mimic phenotype was observed. Lesion mimic plants are well known for their enhanced resistance (Lorrain et al. 2003), such as the spl7, spll1, and splls rice mutants (Table 1). This enhanced resistance often correlates with constitutive expression of defense genes (Lorrain et al. 2003). This is also true for the 11 cases found here showing a lesion mimic phenotype, as constitutive expression of defense markers was found. Thus, in these cases, it is likely that constitutive activation of defense pathway(s) leads to the uncontrolled and constitutive triggering of cell death. Pathogen-inducible over-expression of these genes could reduce this side effect while maintaining high levels of resistance after pathogen infection.

Developmental phenotypes were also often observed (13 cases). In many cases, the plants showed a reduced height that often correlated with enhanced expression of $P R$ genes before infection (Tables 1 and 2). For the genes that are well known to be involved in plant development, increase of disease resistance may in fact be a side effect. This may be true for the GH3.1 and GH3.8 genes that both affect auxin metabolism. In the case of WRKY31, a root phenotype was found (Zhang et al. 2008), further indicating that some side effects may have been missed when looking at aerial parts of the plant only.

Micro-array data are available for five genes $(O S P L D \beta 1$, OsSSI2, OsGH3.1, OsWRKY13, and OsNAC6; Table 1), providing further information on the molecular events that are modified in the corresponding plants. In Osssi2 knockout plants, almost 300 genes are up-regulated, among which a large set of genes related to metabolism (71), transcription factors (32), kinases (28), and defense (16; Jiang et al. 2009). Quite surprisingly, plants overexpressing the WRKY13 gene, besides over-expressing genes of the flavonoid pathway, also displayed upregulation of a large set of genes involved in amino acid (475 genes) and nitrogen (162) metabolism (Qiu et al. 2009a, b). Thus, despite this major transcriptional reprogramming, these plants do not seem to have developmental defects (Qiu et al. 2007). In the case of the OsGH3.1 gene, the micro-array data are consistent with the developmental phenotype. Almost 500 genes related to growth and cellular morphology are down-regulated in the plants overexpressing the OsGH3.1 gene (Domingo et al. 2009). Also consistent with the improved tolerance to dehydratation and high-salt concentrations, genes related to response to abiotic stress are differentially regulated in the mutant.

There are four reports for which response to abiotic stress was also indicated. This confirms a well-known observation that biotic and abiotic stresses are strongly connected. There were three genes for which there is an antagonism between disease and abiotic stress resistance (OsMAPK5a, OsWRKY13, and AtNPR1; Table 1). In these cases, the impact on abiotic stress could not be predicted and the gain for disease resistance is counterbalanced with the loss of resistance to abiotic stress. The available data do not clearly indicate whether there are cases where biotic stress resistance is improved without affecting abiotic stress resistance. However, there are several examples (Table 1) where abiotic stress resistance does not seem affected. Thus, at this stage, one should carefully examine effects on abiotic stress resistance when manipulating genes involved in biotic stress resistance.

The complex case of the OsNAC6 gene demonstrates that it will probably be difficult to use this category of genes to improve stress tolerance (Nakashima et al. 2007). Plants constitutively over-expressing OsNAC6 are more resistant to $M$. oryzae and abiotic stresses but have abnormal plant growth. To try to circumvent this side effect, the OsNAC6 gene was over-expressed under stressinducible promoters. The resulting plants did not show the initial developmental defect, were resistant to abiotic stress, but were no more resistant to $M$. oryzae.

\section{Transgene strategies}

The vast majority ( $75 \%$; for details, see Tables 1,2 and 3 as well as ESM, Supplemental Tables 1 and 2) of the cases of transgenic plants were made in the japonica subspecies. This is a consequence of the fact that japonica rice is easier 
to transform than the indica type. Nipponbare was the japonica cultivar used in most cases (16 genes), reflecting the fact that this is the original genotype adopted by the rice community for genomic studies.

We only found three examples where inducible promoters were used. In the case of the avirulence gene avrXa27, this was necessary to avoid massive HR cell death triggered by the recognition of the product of the avirulence gene and the corresponding major resistance gene $\mathrm{Xa27}$ (Tian and Yin 2009). In the case of the OsNAC6 transcription factor, this was needed to avoid side effects (growth retardation). Moreover, the permanent activation of some disease signaling pathways caused by the use of a constitutive promoter has a metabolic cost that could be measured in terms of carbohydrate storage losses (see below). In one case of pyramiding, several promoters were used, limiting potential silencing issues (Kim et al. 2003). It is likely that inducible promoters will be required in the future to limit side effects (see below) and yield penalty. Finding such specific promoters is one of the major challenges in this field, and current experiments on whole transcriptome analysis under different biotic and abiotic stresses will provide numerous candidate promoters for cloning.

The vast majority of the favorable effects (46 out of 60) on disease resistance were obtained by over-expressing positive regulators. In the case of the OsRacl gene, a dominant constitutively active form of the protein was used (Thao et al. 2007). For genes that are negative regulators, two main approaches were taken: silencing using RNAi and insertion mutants. In one case, a dominant negative allele was introduced ( $r T G A 2.1$; Fitzgerald et al. 2004).

We only found a few cases (Table 4) of gene pyramiding. The pyramiding was obtained either by crossing individual lines (e.g., Datta et al. 2002) or by cobombardment of separate transgenes (e.g., Kim et al. 2003). We found no example of several transgenes borne on one single T-DNA, indicating that transferring several transgenes in one single transformation event is not a common strategy.

Finally, it should be noted that the general issues relative to GMOs apply for the plants described in this review. For acceptance of these products, marker-free plants will be required. RNAi plants are also likely to be more easily accepted as no new protein is produced, although cosilencing may also lead to unwanted side effects.

\section{Conclusions and recommendations for future transgenic approaches}

Examples of transgenic rice plants expressing genes related to disease resistance have tremendously increased in the past decade. With the publication of the first case of improvement of resistance by over-expressing the Rirlb gene (Schaffrath et al. 2000), more than 60 other cases are now available (Table 1). Besides providing information on the disease regulation networks in rice, they also represent a solid sample of examples for the evaluation of transgenic strategies. The key elements coming from this review are listed in Box 1. Based on the review of these 60 cases, several recommendations can be made.

The 60 genes over-expressed or silenced in rice
- Plant genes
41 rice genes and 5 genes from other plants
5 receptors, 22 signalisation, 9 transcription, 7 PR, 3 other
- Genes from micro-organisms
4 elicitors and 5 with antimicrobial properties
Transgenic strategy
- Promoters
58 cases of constitutive and 3 cases of inducible promoters
- Type of mutant
46 over-expresser constructs, 14 knock-out mutants
- Gene pyramiding
5 cases involving receptor and PR genes
Side effects
- $80 \%$ plants show modified defense expression before infection
- 28 genes induce negative side effects
including 14 lesion mimic phenotypes, 13 developmental defects
Best genes on quantitative and qualitative criteria
pi21, PRm, RBBI2-3, OsDR10, OsDBP, defensins

If examples of gene pyramiding (Table 4) are excluded, this represents the individual examination of the potential of 56 genes (Tables 1, 2, and 3). When excluding genes for which detrimental side effects were observed, only half (28) of the genes remain.

The over-expression or silencing of genes involved in signaling and transcription often leads to negative side effects (e.g., lesion mimics, impaired plant growth; Tables 1, 2 , and 3). Thus, one should be careful when using genes involved in signaling and transcription for transgenic strategies.

Alternatively, inducible promoters should be used to reduce the risk and the extent of side effects. This was done, with some success, with the OsNAC6 gene (Nakashima et al. 2007).

Surprisingly, despite the large number of known secreted proteins from pathogens, only a few were used (e.g., pem G1; Table 3). However, pathogen genes coding for avirulence products may not be the best candidates for transgenic approaches as they often trigger secondary effects.

With the example of impaired root development observed for the OsWRKY31 gene (Zhang et al. 2008), one should carefully characterize transgenic plants. An extensive phenotyping with respect to abiotic stress tolerance and 
development seems to be required to detect subtle side effects. Available data still suggest that it should be possible to improve resistance to biotic stress without negatively affecting abiotic stress resistance.

When applying quantitative requirements for the 28 genes not associated with side effects, a few genes clearly stand out as favorable, depending on the pathogen. For blast disease only, the pi21, PRm, and RBB12-3 genes are amongst the best (disease reduction $>90 \%$ ). For bacterial blight disease only, OsDR10 alone provides more than $95 \%$ reduction of symptoms. For sheath blight only, the best gene so far seems to be the $D m-A M P 1$ gene (Table 1). When applying qualitative and quantitative requirements for the 28 genes without side effects, only a few genes providing resistance to several pathogens can be found. For combined blast and bacterial blight disease resistance, the $O S S B P$ gene is the only one providing increased resistance, although the level of this resistance is rather low (50\%). Defensins (Dm-AMP1 and Rs-AFP2) seem to confer good levels of resistance to both blast and sheath blight. These seven genes are amongst the best genes so far for use in transgenic approaches.

$R$ genes and $P R$ genes seem to be a good class of genes to use for transgenic approaches. Plants over-expressing these genes display very little side effects but strong (but likely not durable) protection effects for $R$ genes as well as for $P R$ genes. Thus, very beneficial and straightforward effects will likely be obtained in future transgenic plants over-expressing $R$ genes and $P R$ genes. Defensins seem to have particularly interesting effects (Table 2). While ignored for a long time in rice, defensins seem to exist in rice (Silverstein et al. 2007). Along with the eight classes of $P R$ genes that have not yet been over-expressed in rice, we also suggest using defensins and other small peptides in future transgenic approaches.

It is obvious that missing data limit the possible analysis. It is likely that many genes show protection effects against several pathogens and multiple isolates of one pathogen. One recommendation would be, for the future, that several pathogens and isolates should be tested.

Although we did not review them here, there are several examples of successful improvement of viral resistance by transgenic approach. Expression of the $R F 2 a$ and $R F 2 b$ genes provided RTBV resistance (Dai et al. 2008). There are also several cases of improvement of RYMV resistance by a transgenic approach (Pinto et al. 1999; Kouassi et al. 2006). In all these cases, no side effects were observed, indicating that except for potential durability issues, these strategies are efficient.

We identified 13 negative regulators for which a beneficial effect was obtained in knockout plants (Table 1). As in the case of the pi21 gene where good alleles exist in nature, one can expect to find interesting alleles of negative regulators by mutational approaches. With this respect, the Tilling technology (Till et al. 2007) opens the possibility of finding agronomically interesting alleles of negative regulators.

It was previously shown with a limited subset of 35 rice genes involved in disease resistance that these genes tend to co-localize with blast disease quantitative trait loci (QTLs). These genes were found in $72 \%$ of the cases in genome areas containing QTLs, and this was significantly different from randomly selected genes (Vergne et al. 2008). In a similar way, the rice genes presented in this updated list of genes involved in disease resistance were tested for colocalization with blast QTLs. For the 41 genes for which favorable disease resistance effects could be produced in transgenic rice (Table 1 and ESM, Supplemental Table 2), $90 \%$ were found in blast QTLs. This further supports the idea that disease regulators probably explain many disease resistance QTLs. Thus, the genes of Table 1 and ESM, Supplemental Table 2 can be used as markers for markerassisted selection.

There are as of yet only a very limited number of examples of gene pyramiding (Table 4). However, these examples are very promising as the corresponding plants show high levels of resistance against several pathogens, and when this was measured, no side effect was observed. Mixed planting of transgenic lines should also be efficient for controlling disease epidemics as shown using wild-type mixtures for blast resistance (Zhu et al. 2000).

It is important to note that the final grain yield has not yet been tested in most cases (e.g., Xa21; Tu et al. 2000). Only two cases of transgenic plants listed here were tested in the field (hrflplants, Table 3; Xa21, chitinase and Bt toxin plants, Table 4). Although more than $285 \mathrm{GM}$ field trials across the world were performed between 1990 and 2008 (http://www.gmo-compass.org/eng/database/plants/64.rice.html), it is difficult to establish how many assays are planted for rice. Thus, most of the results discussed here need to be validated in the field.

Finally, the question of durability of these transgenic plants needs to be addressed. Resistance in transgenic plants over-expressing $R$ genes is likely to be overcome by the corresponding pathogen. We can make this conclusion based on the many natural situations where newly introgressed $R$ genes did not last more than 1 to 2 years in the case of blast (Correa-Victoria et al. 2004). In contrast, rice plants over-expressing $R$ genes for which the corresponding avirulence product is not highly polymorphic could be more durable, as pathogens are less likely to harbor mutations circumventing recognition. We have no knowledge on the durability of resistance conferred by genes like $P R$ genes and regulators. These genes could be more durable than genes for which the corresponding protein is in close contact with the pathogen. In this case, the development by the pathogen of counter-defense systems 
could be more difficult. However, the recent finding that many effectors inhibit plant pathogen defense may lead to poor durability of these solutions. Establishing the durability of the transgenic plants resistant to disease represents a major scientific challenge for the coming decades.

Acknowledgments We are thankful to the members of the PYRIZ group for helpful discussions. Amandine Delteil is funded by a $\mathrm{PhD}$ grant from the Languedoc-Roussillon district and CIRAD.

Open Access This article is distributed under the terms of the Creative Commons Attribution Noncommercial License which permits any noncommercial use, distribution, and reproduction in any medium, provided the original author(s) and source are credited.

\section{References}

Bai Y, Pavan S, Zheng Z, Zappel NF, Reinstädler A, Lotti C, et al. Naturally occurring broad-spectrum powdery mildew resistance in a Central American tomato accession is caused by loss of Mlo function. Mol Plant Microbe Interact. 2008;21(1):30-9.

Ballini E, Morel J-B, Droc Gt, Price A, Courtois B, Notteghem J-L, et al. A genome-wide meta-analysis of rice blast resistance genes and quantitative trait loci provides new insights into partial and complete resistance. Mol Plant Microbe Interact. 2008;21(7):859-68.

Ballini E, Vergne E, Tharreau D, Nottéghem JL, Morel JB. ARCHIPELAGO: towards bridging the gap between molecular and genetic information in rice blast disease resistance. In: Wang GL, Valent B, editors. Advances in genetics, genomics and control of rice blast disease. Berlin: Springer; 2009. p. 417-25.

Campbell M, Fitzgerald H, Ronald P. Engineering pathogen resistance in crop plants. Transgenic Res. 2002;11(6):599-613.

Cao H, Li X, Dong X. Generation of broad-spectrum disease resistance by overexpression of an essential regulatory gene in systemic acquired resistance. Proc Natl Acad Sci USA. 1998;95(11):6531-6.

Chern MS, Fitzgerald HA, Yadav RC, Canlas PE, Dong XN, Ronald PC. Evidence for a disease-resistance pathway in rice similar to the NPR1-mediated signaling pathway in Arabidopsis. Plant J. 2001;27(2):101-13.

Chern M, Fitzgerald HA, Canlas PE, Navarre DA, Ronald PC. Overexpression of a rice NPR1 homolog leads to constitutive activation of defense response and hypersensitivity to light. Mol Plant Microbe Interact. 2005;18(6):511-20.

Cheung M-Y, Zeng N-Y, Tong S-W, Li W-YF, Xue Y, Zhao K-J, et al. Constitutive expression of a rice GTPase-activating protein induces defense responses. New Phytol. 2008;179(2):530-45.

Chujo T, Takai R, Akimoto-Tomiyama C, Ando S, Minami E, Nagamura $\mathrm{Y}$, et al. Involvement of the elicitor-induced gene OsWRKY53 in the expression of defense-related genes in rice. Biochimica et Biophysica Acta (BBA) - Gene Structure and Expression. 2007;1769(7-8):497-505.

Coca M, Bortolotti C, Rufat M, Peñas G, Eritja R, Tharreau D, et al. Transgenic rice plants expressing the antifungal AFP protein from Aspergillus giganteus show enhanced resistance to the rice blast fungus Magnaporthe grisea. Plant Mol Biol. 2004;54 (2):245-59.

Coca M, Peñas G, Gómez J, Campo S, Bortolotti C, Messeguer J, et al. Enhanced resistance to the rice blast fungus Magnaporthe grisea conferred by expression of a cecropin A gene in transgenic rice. Planta. 2006;223(3):392-406.

Consonni C, Humphry ME, Hartmann HA, Livaja M, Durner J, Westphal L, et al. Conserved requirement for a plant host cell protein in powdery mildew pathogenesis. Nat Genet. 2006;38 (6):716-20.

Correa-Victoria FJ, Tharreau D, Martinez C, Vales M, Escobar F, Prado G, et al. Studies on the rice blast pathogen, resistance genes, and implications for breeding for durable blast resistance in Colombia. In: Kawasaki S, editor. Rice blast: interaction and control. Dordrecht: Kluwer; 2004. p. 215-27.

Dai S, Wei X, Alfonso AA, Pei L, Duque UG, Zhang Z, et al. Transgenic rice plants that overexpress transcription factors RF2a and $\mathrm{RF} 2 \mathrm{~b}$ are tolerant to rice tungro virus replication and disease. Proc Natl Acad Sci USA. 2008;105(52):21012-6.

Datta K, Baisakh N, Maung T, Thet KM, Tu J, Datta S. Pyramiding transgenes for multiple resistance in rice against bacterial blight, yellow stem borer and sheath blight. Theor Appl Genet. 2002;106(1):1-8.

Domingo C, Andres F, Tharreau D, Iglesias DJ, Talon M. Constitutive expression of OsGH3.1 reduces auxin content and enhances defense response and resistance to a fungal pathogen in rice. Mol Plant Microbe Interact. 2009;22(2):201-10.

Ekengren SK, Liu Y, Schiff M, Dinesh-Kumar SP, Martin GB. Two MAPK cascades, NPR1, and TGA transcription factors play a role in Pto-mediated disease resistance in tomato. Plant $\mathrm{J}$. 2003;36(6):905-17.

Eulgem T. Regulation of the Arabidopsis defense transcriptome. Trends Plant Sci. 2005;10(2):71-8.

Fitzgerald HA, Chern M-S, Navarre R, Ronald PC. Overexpression of (At)NPR1 in rice leads to a BTH- and environment-induced lesion-mimic/cell death phenotype. Mol Plant Microbe Interact. 2004;17(2):140-51.

Flor HH. Inheritance of pathogenicity in Melampsora lini. Phytopathology. 1942;32:653-69.

Fukuoka S, Saka N, Koga H, Ono K, Shimizu T, Ebana K, et al. Loss of function of a proline-containing protein confers durable disease resistance in rice. Science. 2009;325(5943):998-1001.

Gomez-Ariza J, Campo S, Rufat M, EstopÃ M, Messeguer J, Segundo BS, et al. Sucrose-mediated priming of plant defense responses and broad-spectrum disease resistance by overexpression of the maize pathogenesis-related PRms protein in rice plants. Mol Plant Microbe Interact. 2007;20(7):832-42.

Greenberg JT, Yao N. The role and regulation of programmed cell death in plant-pathogen interactions. Cell Microbiol. 2004;6 (3):201-11.

Hückelhoven R. Cell wall associated mechanisms of disease resistance and susceptibility. Annu Rev Phytopathol. 2007;45(1):101-27.

Hammond-Kosack KE, Parker JE. Deciphering plant-pathogen communication: fresh perspectives for molecular resistance breeding. Curr Opin Biotechnol. 2003;14(2):177-93.

Itoh Y, Takahashi K, Takizawa H, Nikaidou N, Tanaka H, Nishihashi $\mathrm{H}$, et al. Family 19 chitinase of Streptomyces griseus HUT6037 increases plant resistance to the fungal disease. Biosci, Biotechnol Biochem. 2003;67(4):847-55.

Jha S, Tank H, Prasad B, Chattoo B. Expression of Dm-AMP1 in rice confers resistance to Magnaporthe oryzae and Rhizoctonia solani. Transgenic Res. 2009;18(1):59-69.

Jiang CJ, Shimono M, Maeda S, Inoue H, Mori M, Hasegawa M, et al. Suppression of the rice fatty-acid desaturase gene OsSSI2 enhances resistance to blast and leaf blight diseases in rice. Mol Plant Microbe Interact. 2009;22(7):820-9.

Jones JDG, Dangl JL. The plant immune system. Nature. 2006;444 (7117):323-9.

Juge N. Plant protein inhibitors of cell wall degrading enzymes. Trends Plant Sci. 2006;11(7):359-67.

Jwa N-S, Agrawal GK, Tamogami S, Yonekura M, Han O, Iwahashi $\mathrm{H}$, et al. Role of defense/stress-related marker genes, proteins and secondary metabolites in defining rice self-defense mechanisms. Plant Physiol Biochem. 2006;44(5-6):261-73. 
Kawasaki T, Henmi K, Ono E, Hatakeyama S, Iwano M, Satoh H, et al. The small GTP-binding protein Rac is a regulator of cell death in plants. Proc Natl Acad Sci USA. 1999;96(19):10922-6.

Khush G. What it will take to feed 5.0 billion rice consumers in 2030. Plant Mol Biol. 2005;59(1):1-6.

Khush GS. Jena, KK. Current status and future prospects for research on blast resistance in rice (Oryza sativa L.). In: Wang GL, Valent $\mathrm{B}$, editors. Advances in genetics, genomics and control of rice blast disease. Berlin: Springer; 2009. p. 1-10.

Kim J-K, Jang I-C, Wu R, Zuo W-N, Boston RS, Lee Y-H, et al. Coexpression of a modified maize ribosome-inactivating protein and a rice basic chitinase gene in transgenic rice plants confers enhanced resistance to sheath blight. Transgenic Res. 2003;12 (4):475-84.

Kouassi NK, Chen L, Siré C, Bangratz-Reyser M, Beachy RN, Fauquet CM, et al. Expression of rice yellow mottle virus coat protein enhances virus infection in transgenic plants. Arch Virol. 2006;151(11):2111-22.

Krishnamurthy K, Balconi C, Sherwood JE, Giroux MJ. Wheat puroindolines enhance fungal disease resistance in transgenic rice. Mol Plant Microbe Interact. 2001;14(10):1255-60.

Lee SW, Han SW, Sririyanum M, Park CJ, Seo YS, Ronald PC. A type I-secreted, sulfated peptide triggers XA21-mediated innate immunity. Science. 2009;326(5954):850-3.

Li H, Zhou SY, Zhao WS, Su SC, Peng YL. A novel wall-associated receptor-like protein kinase gene, $O S W A K 1$, plays important roles in rice blast disease resistance. Plant Mol Biol. 2009;69(3):337-46.

Liu XQ, Bai XQ, Wang XJ, Chu CC. OsWRKY71, a rice transcription factor, is involved in rice defense response. J Plant Physiol. 2007;164(8):969-79.

Lorrain S, Vailleau F, Balagué C, Roby D. Lesion mimic mutants: keys for deciphering cell death and defense pathways in plants? Trends Plant Sci. 2003;8(6):263-71.

Ma JF, Yamaji N. Silicon uptake and accumulation in higher plants. Trends Plant Sci. 2006;11(8):392-7.

Mader JS, Hoskin DW. Cationic antimicrobial peptides as novel cytotoxic agents for cancer treatment. Expert Opin Investig Drugs. 2006;15(8):933-46.

Makandar R, Essig JS, Schapaugh MA, Trick HN, Shah J. Genetically engineered resistance to fusarium head blight in wheat by expression of Arabidopsis NPR1. Mol Plant Microbe Interact. 2006;19(2):123-9.

Maruthasalam S, Kalpana K, Kumar K, Loganathan M, Poovannan K, Raja J, et al. Pyramiding transgenic resistance in elite indica rice cultivars against the sheath blight and bacterial blight. Plant Cell Rep. 2007;26(6):791-804.

Mei CS, Qi M, Sheng GY, Yang YN. Inducible overexpression of a rice allene oxide synthase gene increases the endogenous jasmonic acid level, PR gene expression, and host resistance to fungal infection. Mol Plant Microbe Interact. 2006;19(10):1127-37.

Mishra NS, Tuteja R, Tuteja N. Signaling through MAP kinase networks in plants. Arch Biochem Biophys. 2006;452(1):55-68.

Mitsuhara I, Iwai T, Seo S, Yanagawa Y, Kawahigasi H, Hirose S, et al. Characteristic expression of twelve rice PR1 family genes in response to pathogen infection, wounding, and defense-related signal compounds (121/180). Mol Gen Genomics. 2008;279 (4):415-27.

Morrissey JP, Osbourn AE. Fungal resistance to plant antibiotics as a mechanism of pathogenesis. Microbiol Mol Biol Rev. 1999;63 (3):708-24.

Nakashima K, Tran L-SP, Nguyen DV, Fujita M, Maruyama K, Todaka D, et al. Functional analysis of a NAC-type transcription factor OsNAC6 involved in abiotic and biotic stress-responsive gene expression in rice. Plant J. 2007;51(4):617-30.

Nishizawa Y, Saruta M, Nakazono K, Nishio Z, Soma M, Yoshida T, et al. Characterization of transgenic rice plants over-expressing the stress-inducible $\beta$-glucanase gene Gns1. Plant Mol Biol. 2003;51(1):143-52.

Noutoshi Y, Ito T, Seki M, Nakashita H, Yoshida S, Marco Y, et al. A single amino acid insertion in the WRKY domain of the Arabidopsis TIR-NBS-LRR-WRKY-type disease resistance protein SLH1 (sensitive to low humidity 1) causes activation of defense responses and hypersensitive cell death. Plant J. 2005;43 (6):873-88.

Ono E, Wong HL, Kawasaki T, Hasegawa M, Kodama O, Shimamoto $\mathrm{K}$. Essential role of the small GTPase Rac in disease resistance of rice. Proc Natl Acad Sci USA. 2001;98(2):759-64.

Pandey SP, Somssich IE. The role of WRKY transcription factors in plant immunity. Plant Physiol. 2009;150(4):1648-55.

Peng H, Zhang Q, Li Y, Lei C, Zhai Y, Sun X, et al. A putative leucine-rich repeat receptor kinase, OsBRR1, is involved in rice blast resistance. Planta. 2009;230(2):377-85.

Peterhänsel C, Lahaye T. Be fruitful and multiply: gene amplification inducing pathogen resistance. Trends Plant Sci. 2005;10(6):257-60.

Peters RJ. Uncovering the complex metabolic network underlying diterpenoid phytoalexin biosynthesis in rice and other cereal crop plants. Phytochemistry. 2006;67(21):2307-17.

Petersen M, Brodersen P, Naested H, Andreasson E, Lindhart U, Johansen B, et al. Arabidopsis MAP kinase 4 negatively regulates systemic acquired resistance. Cell. 2000;103(7):1111-20.

Pinto YM, Kok RA, Baulcombe DC. Resistance to rice yellow mottle virus (RYMV) in cultivated African rice varieties containing RYMV transgenes. Nat Biotechnol. 1999;17(7):702-7.

Qiu D, Xiao J, Ding X, Xiong M, Cai M, Cao Y, et al. OsWRKY13 mediates rice disease resistance by regulating defense-related genes in salicylate- and jasmonate-dependent signaling. Mol Plant Microbe Interact. 2007;20(5):492-9.

Qiu D, Mao J, Yang X, Zeng H. Expression of an elicitor-encoding gene from Magnaporthe grisea enhances resistance against blast disease in transgenic rice. Plant Cell Rep. 2009a;28(6):925-33.

Qiu D, Xiao J, Xie W, Cheng H, Li X, Wang S. Exploring transcriptional signalling mediated by OsWRKY13, a potential regulator of multiple physiological processes in rice. BMC Plant Biol. 2009b;9:74.

Qu L-J, Chen J, Liu M, Pan N, Okamoto H, Lin Z, et al. Molecular cloning and functional analysis of a novel type of BowmanBirk inhibitor gene family in rice. Plant Physiol. 2003;133 (2):560-70.

Qu SH, Liu GF, Zhou B, Bellizzi M, Zeng LR, Dai LY, et al. The broad-spectrum blast resistance gene $P i 9$ encodes a nucleotidebinding site-leucine-rich repeat protein and is a member of a multigene family in rice. Genetics. 2006;172(3):1901-14.

Quilis J, Penas G, Messeguer J, Brugidou C, Segundo BS. The Arabidopsis AtNPR1 inversely modulates defense responses against fungal, bacterial, or viral pathogens while conferring hypersensitivity to abiotic stresses in transgenic rice. Mol Plant Microbe Interact. 2008;21(9):1215-31.

Savary S, Willocquet L, Elazegui FA, Castilla NP, Teng PS. Rice pest constraints in tropical Asia: quantification of yield losses due to rice pests in a range of production situations. Plant Dis. 2000;84 (3):357-69.

Sawada K, Hasegawa M, Tokuda L, Kameyama J, Kodama O, Kohchi $\mathrm{T}$, et al. Enhanced resistance to blast fungus and bacterial blight in transgenic rice constitutively expressing OsSBP, a rice homologue of mammalian selenium-binding proteins. Biosci, Biotechnol, Biochem. 2004;68(4):873-80.

Schaffrath U, Mauch F, Freydl E, Schweizer P, Dudler R. Constitutive expression of the defense-related Rirlb gene in transgenic rice plants confers enhanced resistance to the rice blast fungus Magnaporthe grisea. Plant Mol Biol. 2000;43(1):59-66.

Shah J, Raghupathy V, Veluthambi K. Enhanced sheath blight resistance in transgenic rice expressing an endochitinase gene 
from Trichoderma virens. Biotechnol Lett. 2009;31(2):23944.

Shao M, Wang JS, Dean RA, Lin YJ, Gao XW, Hu SJ. Expression of a harpin-encoding gene in rice confers durable nonspecific resistance to Magnaporthe grisea. Plant Biotechnol J. 2008; 6(1):73-81.

Shimono M, Sugano S, Nakayama A, Jiang CJ, Ono K, Toki S, et al. Rice WRKY45 plays a crucial role in benzothiadiazole-inducible blast resistance. Plant Cell. 2007;19(6):2064-76.

Silverstein KAT, Moskal Jr WA, Wu HC, Underwood BA, Graham MA, Town CD, et al. Small cysteine-rich peptides resembling antimicrobial peptides have been under-predicted in plants. Plant J. 2007;51(2):262-80.

Skamnioti P, Gurr SJ. Magnaporthe grisea cutinase2 mediates appressorium differentiation and host penetration and is required for full virulence. Plant Cell. 2007;19(8):2674-89.

Song FM, Goodman RM. OsBIMK1, a rice MAP kinase gene involved in disease resistance responses. Planta. 2002;215(6):997-1005.

Takakura Y, Che FS, Ishida Y, Tsutsumi F, Kurotani K, Usami S, et al. Expression of a bacterial flagellin gene triggers plant immune responses and confers disease resistance in transgenic rice plants. Mol Plant Pathol. 2008;9(4):525-9.

Takase K, Hagiwara K, Onodera H, Nishizawa Y, Ugaki M, Omura T, et al. Constitutive expression of human lactoferrin and its N-lobe in rice plants to confer dideade resistance. Biochem Cell Biology. 2005;83(2):239-49.

Tao Z, Liu H, Qiu D, Zhou Y, Li X, Xu C, et al. A pair of allelic $W R K Y$ genes play opposite role in rice-bacteria interactions. Plant Physiol. 2009;151(2):936-48.

Thao NP, Chen L, Nakashima A, Hara SI, Umemura K, Takahashi A, et al. RAR1 and HSP90 form a complex with Rac/Rop GTPase and function in innate-immune responses in rice. Plant Cell. 2007;19(12):4035-45.

Tian D, Yin Z. Constitutive heterologous expression of avrXa27 in rice containing the $R$ gene $X a 27$ confers enhanced resistance to compatible Xanthomonas oryzae strains. Mol Plant Pathol. 2009;10(1):29-39.

Till B, Cooper J, Tai T, Colowit P, Greene E, Henikoff S, et al. Discovery of chemically induced mutations in rice by TILLING. BMC Plant Biol. 2007;7(1):19.

Toki S, Hara N, Ono K, Onodera H, Tagiri A, Oka S, et al. Early infection of scutellum tissue with Agrobacterium allows highspeed transformation of rice. Plant J. 2006;47(6):969-76.

Tu J, Datta K, Khush GS, Zhang Q, Datta SK. Field performance of Xa21 transgenic indica rice (Oryza sativa L.): IR72. TAG. Theor Appl Genet. 2000;101(1):15-20.

van Loon LC, Rep M, Pieterse CMJ. Significance of inducible defense-related proteins in infected plants. Annu Rev Phytopathol. 2006;44(1):135-62.

Vergne E, Ballini E, Droc G, Tharreau D, Nottéghem J-L, Morel J-B. ARCHIPELAGO: a dedicated resource for exploiting past, present, and future genomic data on disease resistance regulation in rice. Mol Plant Microbe Interact. 2008;21(7):869-78.

Wang GN, Ding XH, Yuan M, Qiu DY, Li XH, Xu CG, et al. Dual function of rice OsDR8 gene in disease resistance and thiamine accumulation. Plant Mol Biol. 2006;60(3):437-49.

White FF, Yang B. Host and pathogen factors controlling the riceXanthomonas oryzae interaction. Plant Physiol. 2009;150 (4):1677-86

Wong HL, Sakamoto T, Kawasaki T, Umemura K, Shimamoto K. Down-regulation of metallothionein, a reactive oxygen scavenger, by the small GTPase OsRacl in rice. Plant Physiol. 2004;135(3):1447-56.

Xiao W, Liu H, Li Y, Li X, Xu C, Long M, et al. A rice gene of de novo origin negatively regulates pathogen-induced defense response. PLoS ONE. 2009;4(2):e4603.

Xiong LZ, Yang YN. Disease resistance and abiotic stress tolerance in rice are inversely modulated by an abscisic acid-inducible mitogen-activated protein kinase. Plant Cell. 2003;15(3):745-59.

Yamaguchi T, Kuroda M, Yamakawa H, Ashizawa T, Hirayae K, Kurimoto L, et al. Suppression of a phospholipase D gene, OsPLD beta 1, activates defense responses and increases disease resistance in rice. Plant Physiol. 2009;150(1):308-19.

Ye R, Huang H, Yang Z, Chen T, Liu L, Li X, et al. Development of insect-resistant transgenic rice with Cry $1 \mathrm{C}^{*}$-free endosperm. Pest Manag Sci. 2009;65(9):1015-20.

Yin Z, Chen J, Zeng L, Goh M, Leung H, Khush GS, et al. Characterizing rice lesion mimic mutants and identifying a mutant with broad-spectrum resistance to rice blast and bacterial blight. Mol Plant Microbe Interact. 2000;13(8):869-76.

Yuan YX, Zhong SH, Li Q, Zhu ZR, Lou YG, Wang LY, et al. Functional analysis of rice NPR1-like genes reveals that OsNPR1/NH1 is the rice orthologue conferring disease resistance with enhanced herbivore susceptibility. Plant Biotechnol J. 2007;5(2):313-24.

Zeng LR, Qu SH, Bordeos A, Yang CW, Baraoidan M, Yan HY, et al. Spotted leaf11, a negative regulator of plant cell death and defense, encodes a U-box/armadillo repeat protein endowed with E3 ubiquitin ligase activity. Plant Cell. 2004;16 (10):2795-808.

Zhang J, Peng YL, Guo ZJ. Constitutive expression of pathogeninducible OsWRKY31 enhances disease resistance and affects root growth and auxin response in transgenic rice plants. Cell Research. 2008;18(4):508-21.

Zhao B, Lin X, Poland J, Trick H, Leach J, Hulbert S. A maize resistance gene functions against bacterial streak disease in rice. Proc Natl Acad Sci USA. 2005;102(43):15383-8.

Zhu Y, Chen H, Fan J, Wang Y, Li Y, Chen J, et al. Genetic diversity and disease control in rice. Nature. 2000;406(6797):718-22.

Zhu H, Xu X, Xiao G, Yuan L, Li B. Enhancing disease resistances of super hybrid rice with four antifungal genes. Sci China Ser C: Life Sci. 2007;50(1):31-9. 